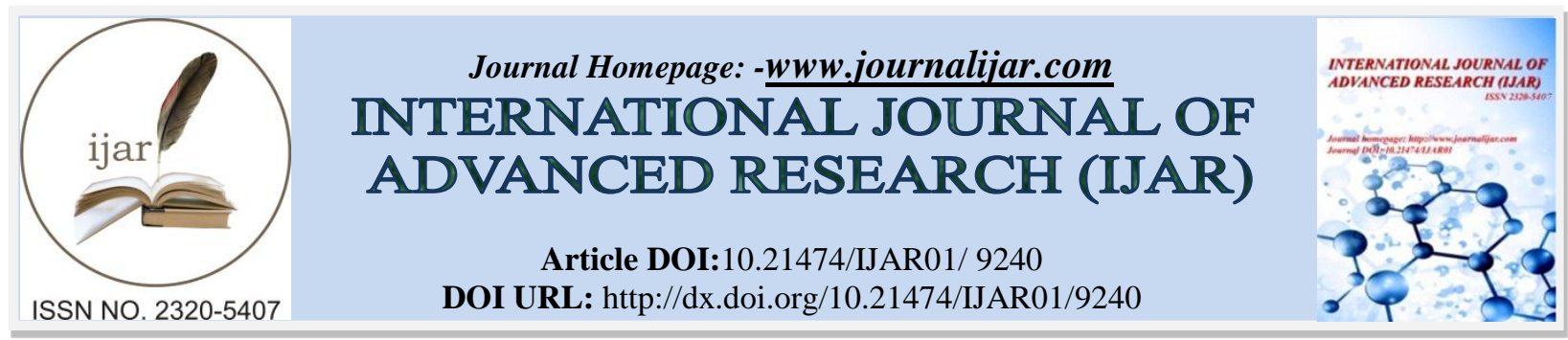

RESEARCH ARTICLE

\title{
MULTIFOCAL BROWN TUMOR REVEALING PRIMARY HYPERPARATHYROIDISM.
}

\author{
M.Badaoui ${ }^{1}$, M.Touati ${ }^{2}$ K.Filali $^{3}$ and S. Louaya ${ }^{4}$. \\ 1. Service de médecine interne Premier centre médico chirurgical-Agadir. \\ 2. Service ORL Premier centre médico chirurgical-Agadir. \\ 3. Service de réanimation Premier centre médico chirurgical-Agadir. \\ 4. Service d'ophtalmologie Premier centre médico chirurgical-Agadir.
}

\section{Manuscript Info}

Manuscript History

Received: 08 April 2019

Final Accepted: 10 May 2019

Published: June 2019

\begin{abstract}
The brown tumor or fibrocystic osteitis is a rare bone lesion secondary to hyperparathyroidism. It can affect the whole bone skeleton with sometimes-infrequent locations. We present a case of multiple brown tumors with unusual bone localization revealed by a phosphocalcic metabolic disorder and primary hyperparathyroidism. After hypocalcemic medical treatment and targeted parathyroid surgery, the evolution was favorable with immediate normalization of parathyroid hormone.This case focuses on the role of $99 \mathrm{mTc}$-Sestamibi functional imaging to optimize the diagnostic orientation and therapeutic strategy of this type of tumor.
\end{abstract}

Copy Right, IJAR, 2019,. All rights reserved.

\section{Introduction:-}

Brown tumors secondary to hyperparathyroidism are rare, historical lesions found in $4.5 \%$ of patients with primary hyperparathyroidism, most often mandibular [1, 2, 3].

Rare cases of localization in the long bones have been reported [1]. They cause osteolytic bone lesions that can mimic a malignant bone tumor.

\section{Observation:}

We report the case of a 42-year-old patient referred for investigation of a diaphyseal tibial bone tumor in a context of deterioration of the general condition.

Clinical examination revealed a fixed, deep, painful palpation at the anterior surface of the upper third of the right tibia.

Standard radiography showed an osteolytic cleft in the middle third of the right tibia with coronary break-in and a periosteal reaction. The phosphocalcic balance showed a hypercalcemia of $126 \mathrm{mg} / 1$ and a hypophosphatemia of 17 $\mathrm{mg} / \mathrm{l}$. The intact PTH was very high at $1200 \mathrm{pg} / \mathrm{ml}$.

The cervico-thoracic CT scan revealed a left lower left parathyroid nodule and very many diseased bone lyses. (Mandibular, scapula, humerus, cranial vault). Proteemia and electrophoresis of serum proteins without abnormalities. After performing a parathyroid scan with Sestamibi 99 Tc Fig1 Surgical excision of the pathological parathyroid pathological process was performed Fig2. 
The anatomopathological study was in favor of parathyroid hyperplasia. The evolution was marked by a spectacular normalization of serum PTH.

\section{Discussion:-}

Brown tumors are benign, osteolytic bone lesions, rare, found in $4.5 \%$ of patients with primary hyperparathyroidism and 1.5 to $1.7 \%$ of those with secondary hyperparathyroidism $[3,4]$.

They can affect the whole skeleton, the most frequent localizations are the pelvis, the ribs, the mandible and the hands [3]. The localization at the level of the long bones in particular the tibia is extremely rare [1,5].

The diagnosis of a brown tumor can sometimes be difficult, mimicking a primary malignant bone tumor or bone metastasis, especially if the lesion is unique and accompanied by inflammatory bone pain evolving in a context of deterioration of the general state [1],

\section{Conclusion:-}

This work focuses on the role of $99 \mathrm{mTc}$-Sestamibi $99 \mathrm{~m}$ TC functional imaging to optimize the diagnostic orientation and therapeutic strategy of this type of tumor.

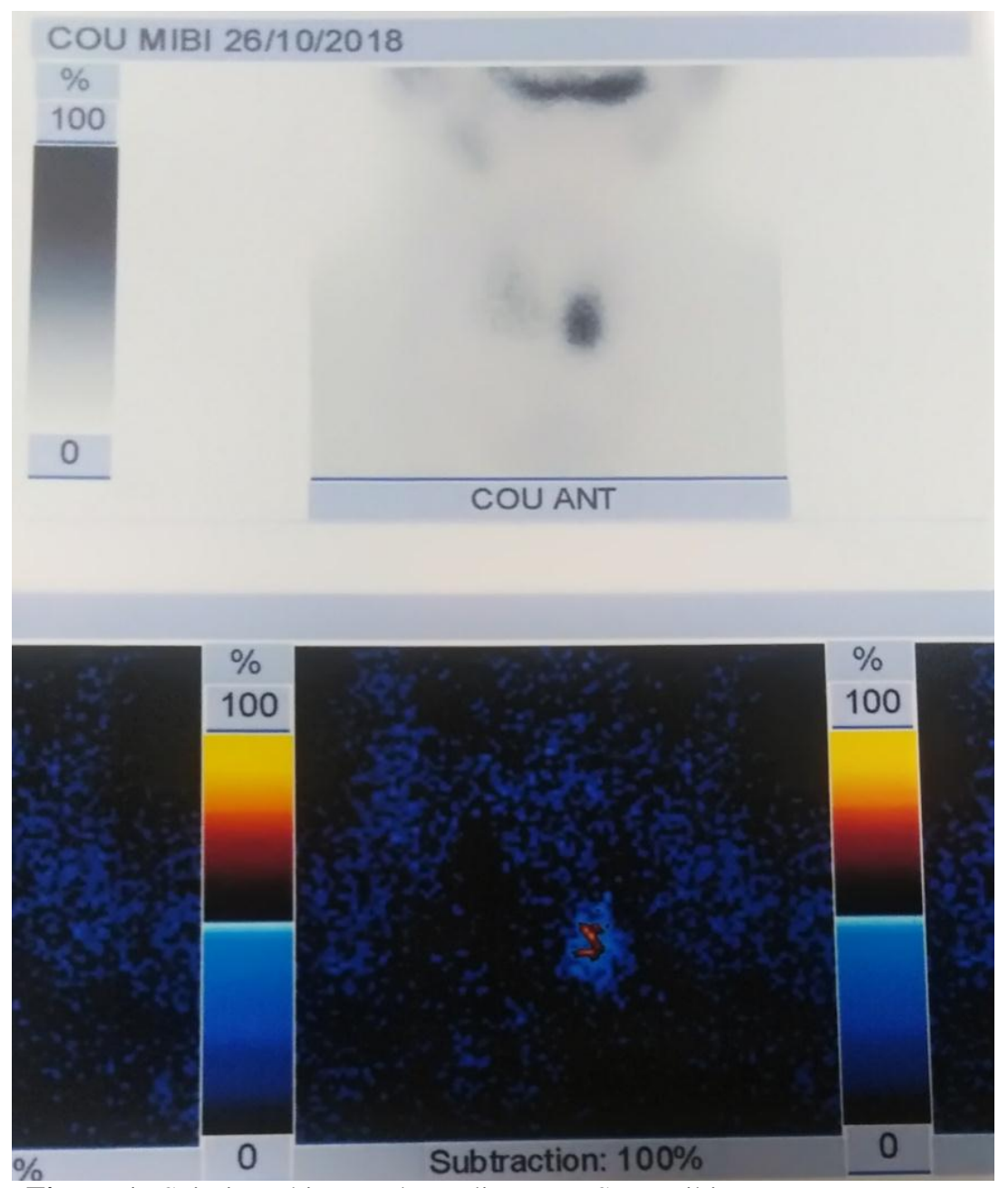

Figure 1:-Scintigraphie parathyroïdienne au Sestamibi 99 Tc. 


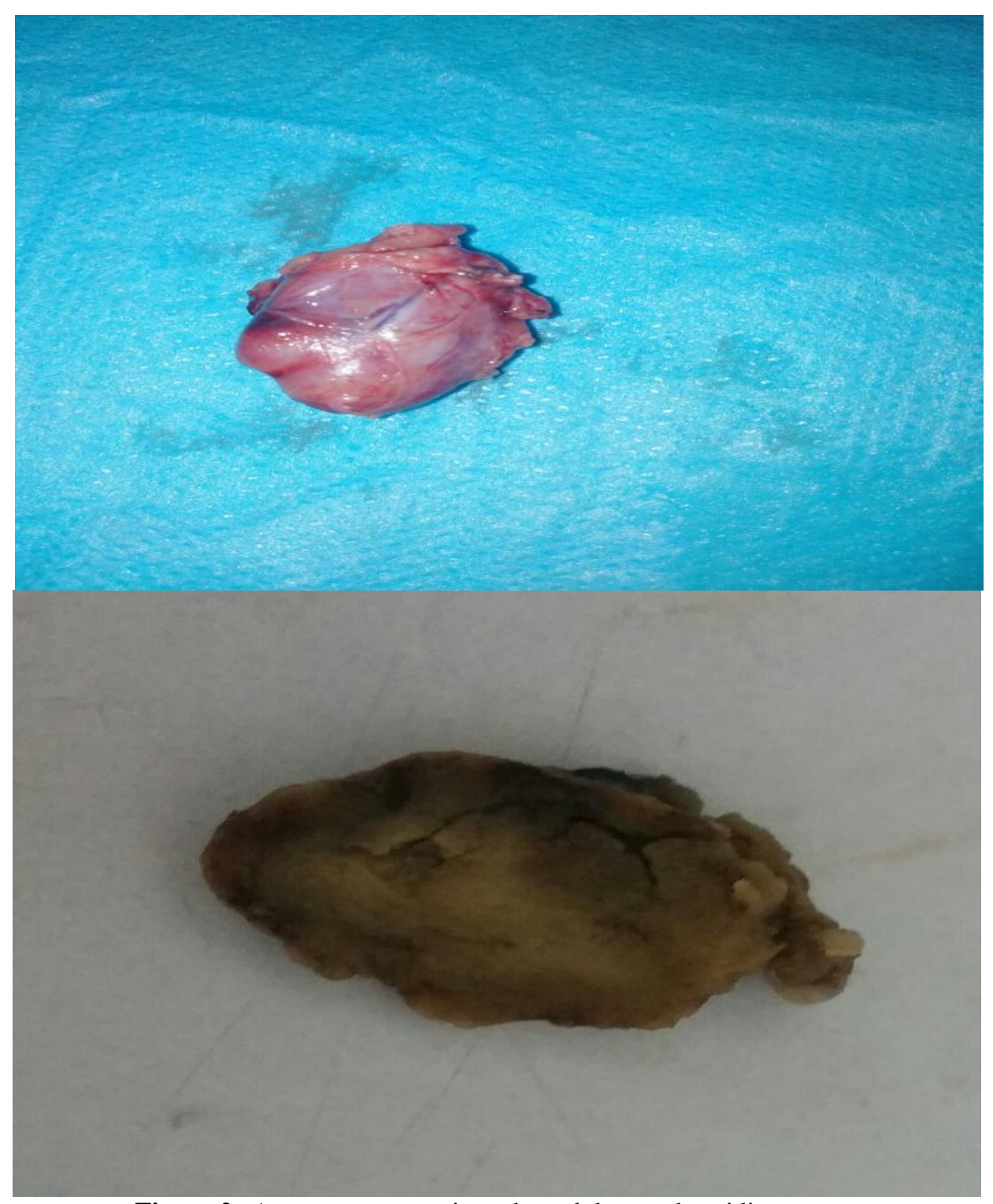

Figure 2:-Aspect macroscopique du nodule parathyroidien.

\section{Bibliography:-}

1. Amani S, Amani MEA, Medeber M. Tumeur brune de l'humérus et hyperparathyroïdie : une maladie rare mimant une métastase osseuse. Annales d'Endocrinologie $2013 ; 74: 294$

2. Nouikes ZS, Bouchair A, Daoudi A. Tumeurs brunes des maxillaires mimant des tumeurs malignes nasosinusiennes révélatrices d'hyperparathyroïdie primaire sévère : à propos de cinq observations. Annales françaises d'Oto-rhino-laryngologie et de pathologie Cervico-faciale 2012 ; 129 :A136

3. Malika F, Taali L, Akssim M. Tumeur brune du maxillaire révélatrice d'hyperparathyroïdie primaire: à propos d'un cas et revue de la littérature. Pan Afr Med J 2013;14:21

4. Keyser JS, Postma GN. Brown tumor of the mandible. Am J Otolaryngol. 1996; 17:407-410.

5. Benabadji N, Benzian Z, Merad MS. Hyperparathyroïdie primaire révélée par une tumeur brune du tibia (à propos d'un cas). Annals d'Endocrinologie $2012 ; 73(4): 355$. 